\title{
On Value Goals of State Governance Modernization
}

\author{
Xiaodong $\mathrm{Li}^{1,2, *}$ \\ ${ }^{1}$ School of Marxism at Beijing Jiaotong University \\ ${ }^{2}$ CITIC Institute for Reform and Development Studies \\ *Corresponding author.Email: xdli@bjtu.edu.cn
}

\begin{abstract}
As the value goals change as per the varying theme of the times, people desired for the unity and harmony during war and unrest years, but fought for democracy and freedom under great empire's ruling. However, at present, as the social conflicts and economic stagnation occur, people are longing for communion and resurgence. The previous goals will become the subsequent tools, namely, the unity and harmony are the precondition to achieve the democracy and freedom, and the democracy and freedom is also the tool to realize the communion-resurgence. As endangering the economic development and social harmony, the western democracy and freedom are lagging behind our time, while the new age needs to construct the new state governance system carrying forward communion and resurgence.
\end{abstract}

Keywords: State-Governance, Modernization, Unity-Harmony, Democracy \& Freedom, Communionresurgence.

\section{INTRODUCTION}

In 2020, we were not only shocked with the horrible number of death and infections from the pandemic COVID-19, but also astonished with the distinct performance between the "decadent" Democracy and "responsive" authoritarianism, with American and China as distinctive representative. People incline to decide that China has been an authoritarian state since 5000 years ago and will never converge with the democracy, but forget the fact that CCP's revolution aimed for democracy and the revolution lasted for 30 years which took millions of people's life. The the socalled "Culture Revolution" again, in some way like the Western youngsters', meant to win democracy back from the authoritarians. Since the convening of the Third Plenary Session of the Eleventh CPC Central Committee in 1978, China's socialist reform has formally kicked off and China moved on its fast-lane of economic growth and governance modernization. The year of 2008 is the 30th anniversary of China's reform and opening up, which truly reflected Confucius' saying of "at thirty, I'm determined", while American financial bomb shocked the world. 2018 marks the 40th anniversary of China's reform and opening up. As Confucius said, "at forty, I had no doubts", the forty years of historical reform experiences enable us to have more definite proposition and stronger willpower upon the developing direction for modernization of state governance [1]. On February 17th, 2014, Xi Jinping delivered an opening ceremony speech at the Workshop of Learning and Implementing the Spirit of 3rd Plenary Session of the 18th CPCCC and comprehensively deepening the reform Attended by the Provincial-andMinisterial-Level Leading Cadres, stressing that "the general objective of comprehensively deepening the reform is to improve and develop the socialism with Chinese characteristics and push on with modernization of the country's governing system and capabilities", and that "China's state governance system needs to be improved and perfected, but we shall have the proposition and willpower regarding how to improve and perfect"[2]104-105. This paper discusses the developing history and practical needs of value goals of state governance modernization from the longer historical span and wider international vision, so as to firmly push the modernized Chinese solutions and Chinese wisdom of state governance system and governance capacity.

\section{FROM WAR \& CHAOS TO UNITY \& HARMONY}

The development $\&$ progress of human society and human civilization originates from the progress of governance system and governance capacity. The human beings are the the master of all things, because of our capacity of self-governance. The internationally 
famous Israeli historian Harari pointed out in his great works Sapiens: A Brief History of Humankind that the clans or tribes generally have fewer population, while the population under the state governance is usually larger than the largest tribe, and the mankind have already been capable of global governance. Different from the mankind, a chimpanzee community generally consists of 20-50 chimpanzees. With the population increase of chimpanzee members, its social order will be shaken. Furthermore, a group of chimpanzees may even kill out another neighboring group of chimpanzees. Even when a valley is especially abundant to raise 500 archaic homo sapiens, they are still incapable of peaceful coexistence, because they cannot determine the issues such as who shall become the leader, who can hunt at which area, who can mate with whom, and etc[3]25. In this case, the governance system and governance capacity of a state that has a such large population but can maintain the peaceful coexistence as China, must have a certain historical progress.

The ancient Chinese tried to conceive the order of human society. As said in the Book of Changes, "Heaven is lofty and honourable; earth is low. (Their symbols), Qian and Kun, (with their respective meanings), were determined (in accordance with this). Things low and high appear displayed in a similar relation. The (upper and lower trigrams, and the relative position of individual lines, as) noble and mean, had their places assigned accordingly. The attributes expressed by Qian constitute the male; those expressed by Kun constitute the female." [4]561 Therefore, the dignity of heaven and man and the humbleness of earth and woman is the natural order, which further produces the political and social order, "Heaven and earth existing, all (material) things then got their existence. All (material) things having existence, afterwards there came male and female. From the existence of male and female there came afterwards husband and wife. From husband and wife there came father and son. From father and son there came ruler and minister. From ruler and minister there came high and low. When (the distinction of) high and low had existence, afterwards came the arrangements of propriety and righteousness." [4]675 In other words, people are born to be different, with the distinctions of male $\&$ female, husband \& wife, father \& son, and ruler \& minister. Therefore, they vary with the highness \& lowness, and nobleness and humbleness. As said in Three Character Classic, "Our Duke of Zhou, drew up the Rites of Zhou, in which he set forth the duties of the six classes of officials; and thus gave a settled form to the government"[5]. It was said in the Book of Rites $\mathrm{Li}$ Yun (also known as: "Ceremonial usages; their origins, development, and intention"), "When the Grand course was pursued, a public and common spirit ruled all under the sky; they chose men of talents, virtue, and ability; their words were sincere, and what they cultivated was harmony.
Thus men did not love their parents only, nor treat as children only their own sons. A competent provision was secured for the aged till their death, employment for the able-bodied, and the means of growing up to the young. They showed kindness and compassion to widows, orphans, childless men, and those who were disabled by disease, so that they were all sufficiently maintained. Males had their proper work, and females had their homes. (They accumulated) articles (of value), disliking that they should be thrown away upon the ground, but not wishing to keep them for their own gratification. (They laboured) with their strength, disliking that it should not be exerted, but not exerting it (only) with a view to their own advantage. In this way (selfish) schemings were repressed and found no development. Robbers, filchers, and rebellious traitors did not show themselves, and hence the outer doors remained open, and were not shut" [6]. In fact, such unified and orderly "Grand Union" world subsequently became China's enduring state governance ideal. The "ultimate state governance" desired by China's Taoism was as follows, "In a little state with a small population, I would so order it, that, though there were individuals with the abilities of ten or a hundred men, there should be no employment of them; I would make the people, while looking on death as a grievous thing, yet not remove elsewhere (to avoid it). Though they had boats and carriages, they should have no occasion to ride in them; though they had buff coats and sharp weapons, they should have no occasion to don or use them. I would make the people return to the use of knotted cords (instead of the written characters). They should think their (coarse) food sweet; their (plain) clothes beautiful; their (poor) dwellings places of rest; and their common (simple) ways sources of enjoyment. There should be a neighbouring state within sight, and the voices of the fowls and dogs should be heard all the way from it to us, but I would make the people to old age, even to death, not have any intercourse with it" [7]. The Taoism highly praised the "governance by doing nothing", which varied from the Confucian "selfcultivation, family harmony, country management and world peace" only in manner and method. However, the targets of both of them are to establish the "unified and orderly" Societal Community.

The unity and harmony is also the ideal of the ancient westerner. The ancient Greek thinker Plato wrote in his The Republic in the voice of Socrates, "When the cobbler or any other man whom nature designed to be a trader, having his heart lifted up by wealth or strength or the number of his followers, or any like advantage, attempts to force his way into the class of warriors, or a warrior into that of legislators and guardians, for which he is unfitted, and either to take the implements or the duties of the other; or when one man is trader, legislator, and warrior all in one, then I think you will agree with me in saying that this interchange and this meddling of 
one with another is the ruin of the State" [8]255-256. In such manner, "A human being who in word and work is perfectly moulded, as far as he can be, into the proportion and likeness of virtue-such a man ruling in a city which bears the same image" [8]253, namely, a properly governed state firstly needs the philosophers who"able to grasp the eternal and unchangeable" [8]230, ensuring that"philosophy ever finds in the State that perfection which she herself is" [8]251. In other words, the mankind must follow the order and morality, instead of laissez faire. The task of state governance is to find the good order and lofty moral standard, so as to design the political system and moral requirements that can realize the good order and lofty moral standard.

Doubtlessly, both the "Grand Union" world desired by the Confucianism and the "Republic" of Plato, contained the much stronger Utopian elements, which were never actually realized on earth. Besides, they also contained the ideological dregs of the distinction between superior and inferior, and mainly represented the interests of the ruling class. However, similar to the big dipper that is inaccessible, but still can guide the mankind to know the developing direction, and also similar to the Beidou navigation satellite system that cannot be blocked by the dark clouds, both the eastern "Grand Union" world and the western "Republic", have always blinked with the light of thought that guides the human civilization $\&$ progress.

The earlier western \& eastern thinkers had pursued the world peace featured in hierarchy and order, because the Confucius lived in the Spring and Autumn period when the Zhou Royal Court was decaying and the dukes vied for hegemony and Plato lived in the times when the Athens Polis was decaying and the Peloponnesian War. Both of them were involved in the wars \& chaos, and desired for the world peace and social harmony. Just as the saying quoted by the Mencius goes, "It is said in the Book of Poetry, "Heaven in producing mankind, Gave them their various faculties and relations with their specific laws. These are the invariable rules of nature for all to hold, And all love this admirable virtue." Confucius said, "The maker of this ode knew indeed the principle of our nature!" We may thus see that every faculty and relation must have its law, and since there are invariable rules for all to hold, they consequently love this admirable virtue"'[9]. All the thinkers who were involved in the wars \& chaos desired for the unified and orderly state and society, considered the world peace as the ideal state of state and social governance, and integrated the life ideal into the order of world peace, which also represented the good wishes of the mass and the grand ideal of the mankind.

It is the prevailing demand of the people who lived in the days of clash of kings and political chaos, to realize the world unity, peace and order. However, the beautiful wish also required the means of its realization, while the grand ideal also required for the realistic conditions of its realization. The Confucius and Plato lived in the days when the nobility was losing its ruling status. Although they provided the beautiful wish and grand ideal, but they were lack of the means and the material basis of its realization, while it was the emerging landlord class who actually grasped the physical means to establish the unified and orderly state. The emerging landlord class were developed on the economic basis variable to the old nobility, while its political ideal was not completely the same as the old nobility. Although their established governance systems and grasped governance capacities were also not the same, their desired political objectives also reflected the prevailing demands of the mass at that time. China's Legalism in the Warring States period represented the interests of the emerging landlord class, greatly challenging the slave state and social governance ideal. The Legalism thought, "The Three Dynasties have attained supremacy by different rites, and the five Lords Protector have attained their protectorships by different laws. Therefore, a wise man creates laws, but a foolish man is controlled by them; a man of talent reforms rites, but a worthless man is enslaved by them" [10]5. However, the Legalism did not think that the rites of the three dynasties, namely, Xia, Shang and Zhou, had the continuity. Instead, the Legalism believed that it was mainly the objection of the latter to the former, and it was also the root cause of kingdom's rising and falling. Therefore, the Legalism also did not believe in the enduring laws and states. Instead, they believed that the leader of a state must continuously reform the rites, so as to ensure that the state could keep on top during the hegemony fighting process. Therefore, "Therefore a sage, if he is able to strengthen the state thereby, does not model himself on antiquity, and if he is able to benefit the people thereby, does not adhere to the established rites" [10]3. Thus, state governance objective of Qin Dynasty is not to rebuild the old order after "the moral degeneration of society is getting worse". Instead, it is to build the new order through "altering the laws and reforming the rites".

The Qin State finally eliminated the other six states through wars, and finally realized the unified and orderly political objective. Although the fighting means of achieving the state unity conducted by Qin State were not generally agreed, such objective was actually the prevailing will of the Chinese after the long-term wars and chaos in the Spring and Autumn and Warring States Periods. Similarly, the western states that suffered from the wars, finally entered into the era of Roman Empire.

At the end of wars and chaos, the human beings entered into the era of unified empire. In $1 \mathrm{BC}$, two cores of the mankind, namely, both the east and west, were under the ruling of kingdom. The small cities and states within the Ganges Basin continuously developed, and finally became the advanced state similar to the eastern and western core areas[11]174. The target of the 
empire is to realize the long-term peace and order of the state, and establish the social peace for all future generations. First Emperor of Qin said, "I am the first emperor. My successors will be successively titled the "Second Emperor", "Third Emperor", and so on through the generations" [12]. Although the Qin Dynasty was perished when it passed to the Second Generation. However, Si Maqian thought, "When the state changes its governance as per the variation of times, it is prone to be successful", and "Please do not directly label the First Emperor Qin with the title of cruelty and tease him because you only observe the short ruling period of Qin Dynasty, only follow the surface records on the historical books, and don't dig into the truth. Such superficial act is almost the same as eating with the ears, while such person is the miserable fool" [13]. Chairman Mao Zedong said, "The political system of First Emperor Qin is executed for hundreds of generations". The Qin empire established the basic political system for China's future governance, including the unification of characters and measurement, the establishment of prime minister and system of prefecture and county, and etc. Without the support of these political systems, it was impossible to realize the objective of unified empire, while the society would fall into the division and chaos once again, and it is impossible to realize the "Grand Union" ideal.

In conclusion, at the early stage of the mankind history, every corner of the world had experienced hundreds of years of wars and chaos, and finally ushered in the the peace and prosperity under the empire governance, this was the so-called "paradox of violence" [11]172. Actually, the empire had always been the most common political system worldwide in the past 2500 years, while most people had lived under the empire system during such period[3]184. Of course, the human society not only shared the "Grand Union", but also had "Minor Differences". From about 500BC to 200BC, it had been the "Axial Period". The China's "Hundred Schools of Thought", the Ancient Greek's Heraclitus \& Plato, Indian Shakyamuni, and other representative figures of the civilizations almost appeared simultaneously, while all the mankind in these three regions began to realize the integrated existence, self and limits of self [14]. As the saying goes, "All roads lead to Rome". Although the human value goals of pursuit of peace and order were almost the same, how to realize the goals varied greatly. Even if adopting the empire political system, Roman Empire and Han Empire varied distinctively.)

\section{FROM UNIFICATION OF THE STATE AND THE CHURCH TO DEMOCRACY AND FREEDOM}

The empire had realized the unified and orderly political objective by force, and also established the governance system in favor of the the empire consolidation. The establishment of the strong empire enabled many people to admire the violence and tease at the pedantry of the Confucius and Plato. However, the empire built on the foundation of violence was not stable, and still under the threat of being divided and perished. Unless obtaining the sincere support from the ruled, the empire would always be fragile. Although the old thoughts could not solve the new problems, they still proposed the similar old problems that would still be encountered in the new era.

The establishment of Qin Empire was a significant milestone of Chinese politics, while the rapid perish of the Qin Empire was also a permanent lesson of Chinese politics. It warned the Chinese rulers that it might be possible to win the kingdom on the back of the horse, but it was impossible to govern the kingdom on the back of the horse. Therefore, at the beginning of Han Dynasty, it implemented the Huang-Lao philosophy and the policy of rehabilitation. Meanwhile, the Han Dynasty also faced the threat of kingdom division and the invasion of Huns, which meant that the unity and order of the empire was not stable. The Emperor Wu of Han, Liu Che, implemented the policy of "Deposed 100, only Confucianism", and earnestly practised the nine standard rules that "all who have the government of the kingdom with its states and families have to follow", namely, "the cultivation of their own characters; the honoring of men of virtue and talents; affection towards their relatives; respect towards the great ministers; kind and considerate treatment of the whole body of officers; dealing with the mass of the people as children; encouraging the resort of all classes of artisans; indulgent treatment of men from a distance; and the kindly cherishing of the princes of the states" [15]. The Confucianism established the moral righteousness and correctness of Chinese empire system, namely, established the "governance ideology" behind the "ruling strategy", and realize the unity of "rule of law" and "rule of virtue". Actually, it was the integration of Legalism, Confucianism and Taoism, and further established the state governance ideology and political system of the integrated Confucianism, Taoism and Legalism, which continuously extended to the end of Qing Dynasty.

In the west, in order to establish its own moral righteousness and correctness, the Roman Empire accepted the Christianity as the state religion. The significance of religion is that it enables the empire system to "have the legitimacy of superman", and that "after having the religion, it is possible to say that laws are not only the design and imagination of the mankind, but also an absolute divine supreme authority. Thus, at least some basic laws will not be shaken, so as to ensure the social stability" [3]200. The Europe, India, Central Asia and other regions and countries, had entered into the reign of religious theology, and implemented the 
political system of unification of the state and the church.

There was a view that after the empire, both the eastern and western civilizations were converted to the religion. At the end of Eastern Han Dynasty, the Yellow Turban Rebellion indicated the rise of Taoism. Meanwhile, Buddhism was also imported into China at the end of Eastern Han Dynasty. Till the $6^{\text {th }}$ century BC, most Chinese, about 30 million, had became the Buddhist[11]202. During the period of Three Kingdoms, Jin, Southern and Northern Dynasties, the Confucianism had already completely declined, and the intellectual represented by Seven Sages of the Bamboo Grove was proud of rebel against Confucianism. Culturally, politically and among the daily life of the mass, the Taoism and Buddhism had already taken the dominant position. The impact of Buddhism upon the politics of the Northern Wei Dynasty might exceed the Confucianism, while the politics of Sui and Tang Dynasties were also deeply influenced by the Buddhism. In the westerner's view, actually, the Confucianism equaled to the religion and might be called the religion of Confucianism. In conclusion, "similar to the first wave of axial thought, the second wave of axial religion was the outcome of social development and change" [11]204, while the religion had became the tool of the empire to consolidate the politics and social order.

After the establishment of the eastern and western empire governance system, the unified and orderly state governance objective was achieved. In order to consolidate and strengthen the empire's governance system and governance capacity, the state governance must pursue the new value goals. No matter what was the nature of Confucianism, namely, whether it was religion or not, it indicated that the unified and orderly empire system was only the method or precondition of state governance at present, while the state governance had the new value goals, namely, to realize the unity and order approved by the Heaven or God. In other words, "the will of God" or "the Mandate of Heaven" had became the value goals of state governance.

Of course, the wheel of history rolled on, while even the religion could not make the empire extend for hundreds of generations. Finally, people realized that the so-called "Divine Right of Kings", "the Mandate of Heaven", and "Son of Heaven", were monkey business. With the rise of bourgeois, the concepts of "Divine Right of Kings", "the Mandate of Heaven", and "Son of Heaven" had already begun to be attacked by the democracy and freedom. The history of human modern civilization started from Europe, while the European modern history commenced from the Renaissance and Enlightenment, while their historical missions were to overthrow the reign of religious theology, and promoted the sense of humanism. Thus, the bourgeois thinkers would also redefine the nature of the state and value goals of governance.

The British bourgeois enlightenment thinker Hobbes firstly proposed the concept of "Natural Right" in his works Leviathan, namely, "Human Rights Endowed by Heaven", or the freedom "to use his own power, as he will himself, for the preservation of his own Nature" [16]97. Thus, the society would be caught in the "war of all against all" [16]94-95. Therefore, the mankind imitated the rational and most excellent work of nature, "Humans"to create the huge monster "Leviathan"named as "Commonwealth or State", which was nothing but an "Artificial Man" [16]1. Obviously, Hobbes enhanced the "Humans" to a much higher status than the "Commonwealth or State", because the "Commonwealth or State" was not divine and it was "Humans" who created the "Commonwealth or State". He thought, "The final cause, end, or design of men (who naturally love liberty, and dominion over others) in the introduction of that restraint upon themselves, in which we see them live in Commonwealths, is the foresight of their own preservation, and of a more contented life thereby; that is to say, of getting themselves out from that miserable condition of war" [16]128. Another British enlightenment thinker Locke also said, "The great and chief end, therefore, of men uniting into commonwealths, and putting themselves under government, is the preservation of their property" [17]. Therefore, it is the most important function of the state was to protect the personal liberty and property safety, while the freedom and democracy had also become the highest value goals of state governance.

Different from the British, the French enlightenment thinker Rousseau said in the subject of the first book of The Social Contract that "Man is born free, and everywhere he is in chains. Here's one who thinks he is the master of others, yet he is more enslaved than they are" [18]8. Although Rousseau said that man was born free, he actually did not think so. Instead, he thought that man was born in chains. He thought, "Yet the children remain attached to the father only for as long as they need him for their preservation; as soon as this need ceases, the natural bond is dissolved. ...... If they remain united, this is something they do not naturally but voluntarily, and the family itself is then maintained only by agreement" [18]9. Therefore, in the opinion of Rousseau, man was not born free, but born to desire for the freedom, release from the attachment, and obtain the equality and freedom. Man was not born free, because children remained attached to the parents only for as long as they needed them for their preservation. However, "as soon as he can think for himself he is the sole judge of the right way to take care of himself, which makes him his own master"'[18]9. Since then, the Hobbes problem occurred, namely, "Find a form of association that will bring the whole common force to bear on defending and protecting each associate's 
person and goods", which was the basic problem that is solved by the "social contract" or "state creation" [18]23. Therefore, the freedom defined by Rousseau was different from that defined by Hobbes, while it meant "makes him his own master", which was actually democracy and equality, and also meant freedom.

Hobbes and Rousseau had variable opinions in terms of the origin, creation and function. With regard to the origin, Hobbes thought that the state was derived from preventing the individuals from fighting with each other for existence, while Rousseau thought the state was derived from enabling the individuals to release the attachment to others for existence. Hobbes considered the state as "Artificial Man", while people created the state, for "the foresight of their own preservation, and of a more contented life thereby", and for the better life throughout. Rousseau considered the state established through the "Social Contract" as the "General Will". To protect the social compact from being a mere empty formula, therefore, "it silently includes the undertaking that anyone who refuses to obey the general will is to be compelled to do so by the whole body" [18]29. Such difference finally led to the distinction between the individualism and liberalism represented by the Britain and USA, and the European collectivism and democracy represented by France. Until now, there is still the obvious difference of political ideas and systems between the Britain \& USA, and the Europe. Of course, the similarities between the Hobbes and Rousseau was also obvious, namely, both of them, no matter it was democracy or freedom, objected the theocracy and pursued the humanism. Both of them represented the political appeal of the Bourgeois rule replacing the feudal nobility rule, and agreed that the reason way the mankind entered into "the state is peace and security of life. Thus, any state where people live a harmonious life and the public security is good, is the best state" [19].

The difference of democracy and freedom concepts between Britain and France finally led to their variable governance system. Although the USA was rooted in the Europe, it was impossible for it to copy the inconsistent European political system. The subsequent Germany also created the governance system differing from that of Britain, USA and France. The reason was that once a state realized the national and state independence, the value goals of democracy and freedom would be achieved. Then, the democracy and freedom would become the means to realize the much higher value goals, namely, become the governance system that could enhance the state governance capacity.

During the period when the bourgeoisie carried out the revolution against the imperialism and feudalism, such as the 1960 British Glorious Revolution, 1776 American Revolutionary War, and 1789 French Revolution, the mass obtained a certain freedom and liberty, and a certain democratic rights, because of the overturn of feudal monarchical dictatorial system and colonialism.

During a long-term history after the mankind entered into the modern times, the bourgeois democracy and freedom actually became the "universal value" accepted by the people worldwide, while the bourgeois political system actually became the political system generally desired by every country in the world. The revolution led by Sun Yat-sen intended to establish the liberal democracy political system, while the May Fourth Movement advocated the values of freedom and democracy. On June 15th, 1949, Mao Zedong delivered a speech on the preparatory meeting of new Political Consultative Conference, definitely proposing that the CPC would lead the Chinese people to establish the "democratic coalition government", and "step on the road to independence, freedom, peace, reunification and prosperity" [20]. In 1945, after listening to the words of "The rise of something may be fast, but its downfall is equally swift." said by Huang Yanpei who noted that history is a testament to an observation that no form of government - an empire, a kingdom, a republic, and so on - had ever been able to break out of a cycle of rise and fall, Mao Zedong replied, "We've already discovered a new path. We can break out of this cycle. This new path belongs to the people" [21]. During the process of promoting the reform and opening up, Deng Xiaoping said, "Without democracy, there is no socialism, and no socialist modernization" [22]. It was definitely proposed in the Communist Manifesto that"In place of the old bourgeois society, with its classes and class antagonisms, we shall have an association, in which the free development of each is the condition for the free development of all"[23]. Besides, China's Core Socialist Values advocated today also include the contents of democracy and freedom.

Of course, just as Marx and Engels wrote in the German Ideology, "It follows from this that all struggles within the State, the struggle between democracy, aristocracy, and monarchy, the struggle for the franchise, etc., are merely the illusory forms-the universality generally took on the form of illusory community-in which the real struggles of the different classes are fought out among one another" [24]84. Besides, the "universal values" of democracy and freedom advocated by the west took on the "form of illusory community" and "For each new class which puts itself in the place of one ruling before it, is compelled, merely in order to carry through its aim, to represent its interest as the common interest of all the members of society" [24]100. Although the Communist also pursued the values of democracy and freedom, but the democracy said by Mao Zedong was the "New Democracy", and the democracy said by Deng Xiaoping was socialist democracy, both of which had variable 
essential connotation and organizational form from the western democracy.

The democracy and freedom was the value goals generally pursued by the mankind since the modern times, while the particularity of specific contents of democracy and freedom could not neglect the universality of democracy and freedom. Anyhow, "the universality generally took on the form of illusory community", namely, as the "universal values", the democracy and freedom could not escape from the "form of illusory community" and become the actual democracy and freedom, until they became the tool to realize the specific community, namely, the interest of a certain class.

\section{FROM DEMOCRACY \& FREEDOM TO COMMUNION-RESURGENCE}

On May 4th, 2014, Xi Jinping delivered a speech at a symposium with the faculty and students of Peking University, stressing that "every era has its own spirit and values" [2]168. In the age of war and revolution, people sacrificed their lives for democracy \& freedom. However, during the times of peace and development after the victory of the revolution, people needed to realize the much higher value goals through democracy and freedom.

The CPC carried on the revolution for the value goals of democracy and freedom, but after the foundation of new China and the completion of socialist transformation, Mao Zedong delivered a speech "On the Correct Handling of Contradictions Among the People", stressing that "Democracy as such sometimes seems to be an end, but it is in fact only a means. Marxism teaches us that democracy is part of the superstructure and belongs to the realm of politics. That is to say, in the last analysis, it serves the economic base. The same is true of freedom" [25]321. On September 21st, Xi Jinping delivered a speech on Speech at the Meeting Marking the 65th Anniversary of the Founding of the Chinese People's Political Consultative Conference , stressing that democracy is not an ornament to be used for decoration; it is to be used to solve the problems that the people want to solve[26]296. The opinion of taking the democracy as the means had been agreed by more and more western scholars and politicians. Besides, democracy was not the only significant value goals or means, and the centralism on the contrary was also the significant political value or means. As stressed by Tu Weiming, although the democracy, freedom and human rights were the universal values, the compassion, justice, comity and responsibility were also the universal values [27]. In 1957, Mao Zedong definitely pointed out that "our aim is to create a political situation in which we have both centralism and democracy, both discipline and freedom, both unity of will and personal ease of mind and liveliness, which is in favor of the socialist revolution and socialist construction, makes it much easier to overcome the difficulties, and much faster to construct China's modern industries and modern agriculture, and also makes the position of CPC and state be more consolidated and enables them to withstand risks" [25]543. After the victory of the revolution, the CPC mainly considered the democracy and freedom as the means of state and governance, considered their opposition, namely, centralism and discipline as the equally significant means, and also adhered to the state system of the people's democratic dictatorship and the organizational principle of democratic centralism, which was the root cause to maintain the enduring peace \& order, and the prosperity and progress in China.

For most developing countries, the political democracy and national unification were equally important, so did the free election \& political order, and the personal rights and social responsibilities. As the significance of the values "opposite to" the democracy, freedom and human rights, the so-called "democratization" transition became the disasters of splitting sovereign, political volatility and social conflict [28].

Democracy was previously the thought weapon of overthrowing the feudal autocracy, and emancipating the productive forces and the mass. However, after the bourgeoisie replaced the feudal landlord, and became the ruling class, the democracy and freedom gradually became the cage of mind by which the bourgeoisie ruled the mass. In order to protect the personal freedom and private properties, the bourgeoisie became increasingly dependent on the political strength, such as laws, beliefs, etiquette, education, and illusion, and the emotional strength, such as public opinions, hints, personal dreams, social religion, arts, and social assessment, so as to conduct the social control[29]. These emotional and political strengths might also be called the social control force, while the democracy and freedom were demonstrated as the stability of political system and national control force upon the society. Therefore, any state where the political system of freedom and democracy was not established would be considered as the state with enormous potential instability and risk of being easy to collapse. The socialist countries and other Third World countries were such countries, while the Revolutions of 1989 and dissolution of the Soviet Union proved that freedom and democracy was the best political system to realize the long-term peace and order of the state. Joseph S.Nye proposed that the comprehensive national power competition should include the "hard power" dominated by the military and economic power, and the "soft power" dominated by the attractiveness of culture, policies and ideology [30]. 
However, if the Revolutions of 1989 and dissolution of the Soviet Union could demonstrate that freedom and democracy was the best political system, the American financial crisis of 2008 and global economic recession resulted therefrom also necessarily and robustly demonstrated the failure of democracy and freedom political system. On April 17th, 2014, the Economist magazine published the long cover article What's Gone Wrong with Democracy?, stressing that "Democracy is going through a difficult time", and "Within the nonwestern societies, the democracy repeatedly collapsed. Within the western societies, the democracy was often linked with the words of becoming debt-ridden, operating failure, and etc" [31]254. This paper thought that the major cause for the democracy losing its glory were the comparison between the financial crisis and China's rise, which convinced the Chinese that the CPC's stable Meritocracy were more efficient than the democracy[31]255-263. The author of What Democracy is for?, Stein Ringen, thought that the purpose of democracy is not for itself, but for better serving the public. Therefore, he appealed to the fellow political scientists to have less procedures and process that stressed the democracy, but have more concerns about the substantive issues of whether the democracy system can better serve the public [32]. The former British Prime Minister Tony Blair also thought, "the values of democracy is correct, but the democracy often could not realize these values. In the ever-changing world, the states, communities, and enterprises must continuously adjust themselves to adapt such changes, while the democracy system seems to be sluggish, bureaucratic and fragile" [33]182. In other words, it was not that the democracy should not be used as the political ideal or value goals. Instead, it was not enough for democracy to give the election rights to the public, while the tangible outcomes were also required [33]185. The political scientist Francis Fukuyama pointed out in his book What Is Governance? that the current prevailing opinions of development studies believed that the democracy and good governance were mutually promoted, and that I believed that this was more of a theoretical hypothesis, and not actually verified by the experiences[34].

Although the democracy and freedom was considered as the governance system, they still lacked of the governance capacity, which was the root cause of why the values of democracy and freedom were suspected. As the superstructure, if the democracy and freedom could not serve the economic foundation, it would definitely be collapsed. If it was possible to liberate and develop the productive force, the new political superstructure would definitely appear, and solve the problems of new era and realize the value appeals of the new era.

The primary reason of why the values of democracy and freedom lost their glory was their failures in promoting the development of productive forces. Samuel Huntington said, "What makes the culture and ideology become attractive? When they are considered as the victory and impacts rooted in materials, they are attractive" [35], namely, the attraction of democracy and freedom political system was based on the American prosperity. Therefore, the professor Michael E.Porter from the American Harvard Business School said, "on the state level, the only meaning of "competitiveness" is the national productive force. The enhancement of national standard of living required the enterprise to continuously enhance and create the productive force conforming to the requirements of the era" [36]. This was to stress the significance of development, while the American President Trump was elected with the slogan of "Make America Great Again", indicating that the Americans generally agreed to take the development as the primary target of state governance.

However, as the USA was the most advanced country worldwide, it was not accurate to say "development" was the primary objective of American governance. Therefore, the campaign slogan of Trump "Make America Great Again", actually was to realize the "resurgence" target of the American nation. In other words, the American development was declining in relative terms, while the USA needed to revive its past strength, which was the primary objective of American governance, or at least the general will of the American citizens. "resurgence" was not only the primary objective of China's state governance, but also the primary objective of major countries worldwide today. Similarly, the Russia's largest goal was to realize the resurgence of Russia, while India's largest goal was also to realize the resurgence of India. The Britain, France, Germany, Italy, Spain, Portugal, Netherlands and other European countries also desired to reestablish the global position of its own nation or Europe. Even the Turkey, Iran, Mongolia, and other countries, also often took the glory of the empire as the value goals of state governance.

The development was the only way to realize the resurgence. "Development is the primary task, which is applicable to every country" [26]542. However, it was equally important that "the richest one percent of the world's population own more wealth than the remaining 99 percent. Inequality in income distribution and uneven development space are worrying" [26]480. The French economist Thomas Piketty said in his book Capital in the Twenty-First Century, "Capitalism unconsciously caused the uncontrollable and unsustainable social inequality, which fundamentally destroyed the elite values based on the democratic society" [37]. The slogan of the American "Occupy Wall Street" was "We are the 99\%", which expressed the demands that the American citizens wanted to share the development. Similarly, internationally, the American president Trump proposed the "America First" foreign policy, 
vigorously promoted the trade protectionism, and even launched the trade war and threatened the other countries with the military powers and wars, while such state governance concept could neither brought the development chance for the American citizens, but also definitely met with widespread opposition worldwide.

President Xi Jinping stressed "The joint development is the true development and the sustainable development is the good development" [26]524, "Our aim is to achieve more balanced development and ensure that the people have equal access to opportunities and share in the benefits of development" [26]482. Besides, he also stressed that "Peace, development, equity, justice, democracy and freedom are common values of all mankind" [26]522. The peace and development is still the theme of our times, while the democracy and freedom is still the value goals that we still pursue. However, the peace and development issue is mainly demonstrated as the fight and struggle resulted from the national and social divisions, while the democracy and freedom issue is mainly demonstrated as the protest against the unbalanced and inadequate development, and the equality and justice becomes the more and more prominent themes of our times. On the basis of peace and development, the most significant value goals of the state governance are to realize the national rejuvenation and shared development through mobilizing the public initiative, enthusiasm and creativity by democracy and freedom.

\section{CONCLUSION}

In conclusion, "The original aspiration and the mission of Chinese Communists is to seek happiness for the Chinese people and rejuvenation for the Chinese nation" [38]. The state governance of CPC not only stressed realizing the Chinese Dream of national rejuvenation, but also stressed the "people-centered shared development" [39]. The CPC took the rejuvenation and sharing as the primary value goals of state governance, which transcended the old mindset of taking the democracy and freedom as the evaluation criteria of state governance modernization, and established the moral criteria and action guidelines for the great rejuvenation of the Chinese nation, and the peace $\&$ happiness of the Chinese people.

\section{AUTHORS' CONTRIBUTIONS}

This paper is partly the result of the program"rejuvenation and co-sharing, the Research on What Communism means for the Communist Party of China"supported by National Social Science Fund of China (No. L19N500010), the author is grateful for the endowment.

\section{ACKNOWLEDGMENTS}

The author is very grateful for the Journal of Socialism Core Values by Tsinghua University which in 2018 published most of this paper in Chinese.

\section{REFERENCES}

[1] Li Xiaodong \& Li Dan, Doubtless at Forty: 40 Years of Reform Has Built the Power-mind of State Governance Modernization [J], Cognition and Practice, 2018 (1): 26-31.

[2] Xi Jinping, The Governance Of China [M], Beijing: Foreign Languages Press, 2014.

[3] [Israel] Yuval Noah Harari, Sapiens: A Brief History of Humankind [M], Beijing: China CITIC Press, 2017.

[4] Translated \& annotated by Yang Tiancai \& Zhang Shanwen, Book of Changes, Beijing: Zhonghua Book Company Limited, 2011.

[5] Translated \& annotated by Li Yi'an \& Zhang Limin, The Three-Character Classic | The Book of Family Names | The Thousand-Character Classic | Disciple Gauge | Poems of 1000 Masters [M], Beijing: Zhonghua Book Company Limited, 2011, 22.

[6] Translated and explained by Wang Wenjin, Translation \& Explanation of Book of Rites [M], Beijing: Zhonghua Book Company Limited, 2001, 287.

[7] Translated \& annotated by Tang Zhangping \& Wang Zhaohua, Book of Laozi [M], Beijing: Zhonghua Book Company Limited, 2014, 299.

[8] [Ancient Greek] Plato, The Republic [M], Beijing: Commercial Press, 1986.

[9] Translated \& annotated by Fang Yong, The Works of Mencius [M], Beijing: Zhonghua Book Company Limited, 2015, 219.

[10] Translated \& annotated by Shi Lei, The Book of Lord Shang $[\mathrm{M}]$, Beijing: Zhonghua Book Company Limited, 2011.

[11] [USA] Written by Ian Morris, Translated by Qian Feng, Why the West Rules-For Now: The Patterns of History, and What They Reveal About the Future [M], Beijing: China CITIC Press, 2014.

[12] Sima Qian, Records of the Grand Historian (Volume 1) [M], Beijing: Zhonghua Book Company Limited, 2013: 304.

[13] Sima Qian, Records of the Grand Historian (Volume 2) [M], Beijing: Zhonghua Book Company Limited, 2013: 836. 
[14] [German] Written by Karl Jaspers, Translated by Wei Chuxiong \& Yu Xintian, The Origin and Goal of History [M], Beijing: Huaxia Publishing House, 1989, 7-8.

[15] Translated \& annotated by Chen Xiaofen \& Xu Ruzong, The Analects of Confucius, The Great Learning \& The Doctrine of the Mean [M], Beijing: Zhonghua Book Company Limited, 2011, 324.

[16] [British] Thomas Hobbes, Leviathan [M], Beijing: Commercial Press, 1985.

[17] [British] John Locke, Two Treatises Of Civil Government [M], Beijing: Commercial Press, $1984,77$.

[18] [France] Jean-Jacques Rousseau, The Social Contract [M], Beijing: Commercial Press, 1980.

[19] [Netherlands] Baruch de Spinoza, Treatise on Theology and Politics [M], Beijing: Commercial Press, 1999, 41-42.

[20] Mao Zedong, Selected Works of Mao Zedong (Volume 4) [M], Beijing: People's Publishing House, 1991, 1464-1465.

[21] Liu Yiqing, Before and after the Publishing of Huang Yanpei, Return from Yan'an [J], China Reading Weekly, 2013-04-24: 14.

[22] Deng Xiaoping, Selected Works of Deng Xiaoping (Volume 2) [M], Beijing: People's Publishing House, 1994, 168.

[23] Marx \& Engels Collected Works (Volume 2) [M], Beijing: People's Publishing House, 2009, 53.

[24] Marx \& Engels Collected Works (Volume 1) [M], Beijing: People's Publishing House, 1995.

[25] Mao Zedong, Mao Zedong's Draft Manuscript since the Foundation of People's Republic of China (Volume 6) [M], Beijing: Central Party Literature Press, 1992.

[26] Xi Jinping, The Governance Of China (Volume 2), Foreign Languages Press, 2017.

[27] Chen Lai \& Gan Yang, Confucius and Contemporary China [M], Beijing: SDX Joint Publishing Company, 2008: 19.
[28] Li Xiaodong \& Li Haixia, The Great Failure of the Western Democracy [J], Journal of Tangshan Normal University, 2015 (3): 117-120.

[29] [USA] Edward Alsworth Ross, Social Control [M], Beijing: Huaxia Publishing House, 1989, 313.

[30] [USA] Joseph S.Nye, Hard \& Soft Power [M], Beijing: Peking University Press, 2005: 107-108.

[31] What's Gone Wrong with Democracy? [M], Beijing: Learning Press, 2014.

[32] Stein Ringen, What Democracy is for? [M], Beijing: Xinhua Publishing House, 2012, Foreword No. 2.

[33] What's Wrong with Western Democracy (Volume 3) $[\mathrm{M}]$, Beijing: Learning Press, 2015.

[34] Written by Francis Fukuyama, Translated by Zheng Huan, What Is Governance? [J], Journal of National Academy of Education Administration, 2013 (6): 19-27.

[35] [USA] Samuel Huntington, The Clash of Civilizations and the Remaking of World Order [M], Beijing: Xinhua Publishing House, 2002: 8889.

[36] [USA] Written by Michael E.Porter, Translated by Li Mingxuan \& Qiu Meiru, The Competitive Advantage of Nations [M], Beijing: Huaxia Publishing House, 2002, 6.

[37] [France] Written by Thomas Piketty, Translated by Ba Shusong et al., Capital in the Twenty-First Century, Beijing: China CITIC Press, 2014: 2.

[38] Xi Jinping, Secure a Decisive Victory in Building a Moderately Prosperous Society in All Respects and Strive for the Great Success of Socialism with Chinese Characteristics for a New Era Delivered at the 19th National Congress of the Communist Party of China [R], Beijing: People's Publishing House, 2017, 1.

[39] Li Xiaodong \& Chen Shuwen, People-Centered Shared Development: Socialist Ethical Foundation \& Spiritual Pursuit [J], Theoretical Study of Mao Zedong \& Deng Xiaoping, 2017 (5), 45. 